\title{
How do Students' Mastery and Performance Goals Relate to Math Anxiety?
}

\author{
Joseph M. Furner and Alyssa Gonzalez-DeHass \\ Florida Atlantic University, Florida, USA
}

Received 31 January 2011; accepted 01 August 2011

A changing, economically competitive world has necessitated reform in mathematics education. Yet mathematics anxiety has been a prevalent concern among educators and others in our society for decades. Some students tend to be more anxious about the testing process and can often freeze up, others just cringe when they are confronted with any form of computational exercise, or others dread taking math classes which can occur in the elementary, middle, high, and even at the college levels. Educators, parents, politicians, and others are trying to assess the cause for the apparent academic weakness of mathematics, and solutions to the problem are being sought. Our focus in this paper is to tease apart the underlying causes of math anxiety that result from a teacher's instructional practice, particularly how mastery and performance goals relate to the construct of math anxiety, and how a teachers' understanding of creating mastery-oriented classrooms can help to prevent or reduce the anxiety students experience during mathematics. Research indicates that classroom practices can influence the goals students adopt, and that educators should strive to create mastery-oriented classrooms by examining the nature of the tasks they assign students, the authority or degree they involve students in academic decision-making, the types of evaluation and recognition they utilize, and the classroom climate they create.

Keywords: Math anxiety, goal orientation, STEM Fields, Decision Making, career choice, attitudes, teaching strategies, mastery learning

\section{INTRODUCTION}

Math anxiety is a real issue that can impact a young person's goals, many career-related decisions they may make in life, and their overall future. A changing, economically competitive world has necessitated reform in mathematics education and continues to do so. With the expanding use of computer technology, the need for the understanding of mathematics is critical. The US is working quickly to attract more of its workforce in the STEM (Science, Technology, engineering, and

Correspondence to: Joseph M. Furner, Ph.D in Mathematics Education, Florida Atlantic University, College of Education, John D. MacArthur Campus, 5353 Parkside Drive, EC 207, Jupiter,

Florida 33458, USA

E-mail: jfurner@fau.edu
Mathematics) fields. Dawson (Internet) has found that Americans often times are not qualified for many hightech jobs and that companies seek employees outside the U.S. requiring special H1-B Visas. Since the September $11^{\text {th }}$ tragedy, this process may be hampered and the U.S. has no alternative other than to better prepare its students in the areas of math, science, and technology. Yet Dawson (Internet) contends that our $\mathrm{K}-12$ educational system is not preparing students for future studies in math and science. Lane (1999) emphasizes the critical importance of mathematics and science education for our young people and the contribution they will make to our nation's economy and overall well-being, and contends that we must support high quality mathematics and science education in every way we can so that we are ensured an adequate talent pool for our country. Neunzert (2000) feels that mathematics is critical for people living in the $21^{\text {st }}$ Century for them to be successful and believes we have 


\section{State of the literature}

- Math anxiety is real and exists in our schools, and it impacts the decisions and career choices of young people today.

- Helping students identify and address their math anxiety is critical in helping them cope with and overcome such anxiety that otherwise may negatively impact future choices in their academic and professional careers.

- In an age of high technology and a demand for more people in the STEM fields, teachers need to be trained in working with students with math anxiety in order to employ best practices in the teaching of mathematics to today's youth.

\section{Contribution of this paper to the literature}

- This paper is in response to a real need for creating more young people who have a passion and interest in the STEM fields, people who are confident in their ability to do mathematics and will set goals to pursue academic and professional careers in the area of mathematics and the sciences.

- The focus of this paper is to examine the underlying causes of math anxiety that result from a teacher's instructional practice, particularly how mastery and performance goals relate to the construct of math anxiety.

- The paper closes with a discussion of how a teachers' understanding of creating masteryoriented classrooms can help to prevent or reduce the anxiety students experience during learning mathematics.

to understand ourselves as MINT-professionals: $\mathrm{M}=$ mathematics, $\mathrm{I}=$ informatics, $\mathrm{N}=$ natural sciences, $\mathrm{T}=$ technology.

Today our schools need to start working toward turning more young people onto mathematics and the other STEM fields in order to address achievement goals here in the US, producing more of a workforce for the new demand for high tech, science, and math related jobs. Paralleling this need, the Gallup (2005) Youth Survey found that the American public rated math first in importance when compared with the other academic fields. The poll also stated that there is no question American students could and should be doing better than they are in math. According to this study, only $23 \%$ of U.S. eighth-graders reach the high international benchmark, meaning they can "solve multistep word problems involving addition, multiplication, and division" and "use their understanding of place value and simple fractions to solve problems." (P. 1) Given that more than three-quarters of U.S. students could not meet this threshold, it's not surprising that, according to this latest Gallup Youth Survey, more teenagers name math than any other subject as the course they find most difficult in school.

Mathematics anxiety has been a prevalent concern among educators and others in our society for decades. Educators, parents, politicians, and others are trying to assess the cause for the apparent academic weakness of mathematics, and solutions to the problem are being sought. Teachers at all levels can play a critical role in addressing math anxiety by addressing the fact that their students can achieve at math and overcome such anxiety to pursue any career field they want. Of particular interest to this paper is to tease apart how mastery and performance goals relate to the construct of math anxiety and how a mastery-oriented classroom can help to prevent or reduce the anxiety students experience during mathematics.

\section{Math Anxiety}

\section{Definition and Prevalence}

According to Tobias (1993), a leader on the topic of math anxiety, mathematics anxiety can be defined as feelings of tension and anxiety that interfere with the manipulation of numbers and the solving of mathematical problems in a wide variety of ordinary life and academic situations. Some students tend to be more anxious about the testing process and can often freeze up (math test anxiety), others just cringe when they are confronted with any form of computational exercise (number anxiety), and others dread taking math classes which can occur in the elementary school, middle school, high school, or college levels (math course anxiety). Tobias feels that math anxiety can cause one to forget and lose one's self-confidence. Wells (1994) has identified anxiety as a major factor in blocking students' reasoning, memory, understanding of general concepts, and appreciation for mathematics. Math anxiety is real and many in the US feel great discomfort with anything related to mathematics.

Burns (1998) in her book Math: Facing an American Phobia has found that two-thirds of American adults fear and loathe math. Boaler (2008) in her book, What's math got to do with it? Helping children learn to love their least favorite subject-and why it's important for America shares many concerns about how poor attitudes toward math impact many of the decisions our young people make and the career choices they may choose and or avoid. Evidence of students' poor performance, attitudes and high levels of anxiety toward math is abundant. In the midst of a technological era, declining mathematics (math) scores on the Scholastic Aptitude Test (SAT) have been widely publicized. Golberg and Harvey (1983) reported that American students rank last when compared with 
students from all other industrialized countries on 19 different assessments. The Third International Mathematics and Science Study (TIMSS) has shown a declining trend in U. S. students' math scores as students increase in age group from grade four to twelve (Schmidt, 1998). Hinds, Hom \& Brookshaw (2002) found that about $46 \%$ of high school graduates enrolled in California State Universities need remedial courses in mathematics. According to Callahan, Tomlinson, Reis, and Kaplan (2000), "U.S. 12 ${ }^{\text {th }}$-graders who were taking Advanced Placement calculus, when compared with all advanced mathematics students in other nations, performed only at the international average and significantly higher than students in just five other countries." Steen (1999) points out "national and international studies show that most U.S. students leave high school with far below even minimum expectations for mathematical and quantitative literacy."

\section{Instructional Practices Related to Math Anxiety}

Hilton and Pedersen (1983) contended that math avoidance is a serious malaise of our time and that it has many causes, which can be grouped under three headings: societal, familial, and cultural influences; pedagogy; and curriculum. Causes for math anxiety can include socioeconomic status, parental background, and the influence of teachers and school system (Hackett, 1985; Kutner, 1992). For the purposes of this article, we will focus on the instructional factors that may cause math anxiety, particularly how a teachers' understanding of creating mastery goal-oriented classrooms can help to prevent or reduce the anxiety students experience during mathematics.

According to Williams (1988), mathematics anxiety has its roots in teaching and in teachers of mathematics. Williams stated that because people generally are not math anxious before going to school, math anxiety is related to the teaching of mathematics and the notion that mathematics is something to be dreaded begins in the child's first years in school. Teachers and other significant adults may model that mathematics is difficult and something to fear, whereas at the same time they indicate that mathematical skills are very important for their future success. Tobias (1993) reported that too often teachers play a role in spreading a vicious myth that math ability is inborn and that not all students are good in math. It is important to keep in mind that the first exposure children may have with math will be with their primary teachers who, more than likely, are not trained in math and who are also anxious about math (Harper, 1994; Posamentier, Smith, \& Stepelman, 2009).

Oberlin (1982) discussed the following teaching techniques as causes of math anxiety: (a) assigning the same work for everyone, (b) covering the book problem by problem, (c) giving written work everyday, (d) insisting on only one correct way to complete a problem, and (e) assigning math problems as punishment for misbehavior. Brush (1981) contended that the development of math anxiety carries some symptoms that include the following: (a) mathematics becomes difficult during early years of school, (b) students spend excessive amounts of time relearning what they were taught in past years, and (c) students are not exposed to the everyday applications of the material covered.

Posamentier, Smith, and Stepelman (2009) suggested that there are signals projected by a teacher when a teacher is forced to teach mathematics: math is presented in a somewhat strained tone of voice; it is presented as an arduous task, for both the teacher and the students, to be completed in the shortest time possible; it is taught as a drill or memorization exercise rather than a thinking/problem-solving agent; and it is readily used as a punishment. This form of instruction is certainly enough to scare students, and it is understandable why so many young adolescents begin their first junior high math class in a cold sweat (Posamentier, Smith, \& Stepelman, 2009). Frequently students' first real encounters with math can make them feel incompetent when presented by teachers who do not like math. Then when students go home, they usually they find that their parents do not like math either. Posamentier, Smith, and Stepelman contend that most junior high and senior high mathematics teachers are not prepared to deal with this psychological fear of math, nor are they prepared to deal with the defense mechanisms and strategies their students use to protect themselves from appearing to fail in math.

Crawford (1980) found that a student's lack of success with math may be caused by any one of several factors: a poor math instructor at some point; an insufficient number of math courses in high school; unintelligible textbooks; or misinformation about what math is and what it is not, as well as who should do well in math. Crawford also found that many people often blame their failures on their lack of a mathematical mind, the notion that men are better than women at math, or that they have poor memories or learning disabilities. There are two myths about mathematics that need to be eliminated: that higher-level math is too difficult for otherwise intelligent students to master, and that without mathematics you can live a productive, intellectual and professional life (Tobias, 1987). Students must overcome any fears of mathematics and be challenged to take higher-level math courses; otherwise, this may impact their future career choices.

Test anxiety. Alexander and Martray (1989) suggested that more anxiety was stimulated by math test-related items than numerical task or course-related items on their Abbreviated Version of the MARS. Research 
studies (Alexander \& Cobb, 1984; Resnick, Viehe, \& Segal, 1982; Rounds \& Hendel, 1980) consistently identify math test anxiety to be the major element of math anxiety. In May 1995 the NCTM published a new assessment document providing guidelines for mathematics teachers to assess their students. It seems educators are seeing that the traditional forms of mathematics assessments, such as paper-and-pencil tests, right and wrong answers, timed tests, and following only one right procedure to solve problems, are an ineffective way of assessing students mathematically. The NCTM $(1989,1991,1995 b)$ has realized that there are alternate forms of assessment that are as effective in evaluating student learning in mathematics. The NCTM suggested that teachers should be incorporating more qualitative forms of assessment as well as group assessments, portfolios, rubrics, and observations (NCTM, 1995b). The NCTM indicated that it is important that teachers gather evidence about student's knowledge of, ability to use, and disposition toward mathematics and of making inferences based on that evidence for a variety of purposes.

Anton and Klisch (1995) have done extensive research in the area of mathematics anxiety and how it relates to test anxiety. Anton and Klisch contended that individuals who are high in test anxiety may be similar in some respects to individuals who are math anxious. Hendel and Davis (1978) suggested that the treatment of math anxiety may be functionally similar to test anxiety, and because of these parallels, current conceptions of test anxiety may be useful in clarifying the nature of math anxiety. Conceptions of mathematics anxiety are often difficult to separate from test anxiety as it applies to mathematics; furthermore, test anxiety appears to provide the main source of theoretical support for much of the research on mathematics anxiety (Sarason, 1987).

The construct of test anxiety can also be broken down into sub-components. Math anxiety, like test anxiety, may be composed of two major components: cognitive concerns about performance (worry) and emotionality (autonomic reactions that are evoked by stress, i.e., heart beating faster). Arem (2003) further refined this break-down and proposed that test anxiety is threefold: poor test preparation and test-taking strategies, psychological pressures, and poor health habits. Any or all of these may be the culprit. Posamentier, Smith, and Stepelman (2009) suggested that the goal is to reduce the threat of math anxiety and in order to do this math teachers must reduce the uncertainty associated with testing. Speed tests, timed tests, and deadlines interfere with curiosity and question-asking behaviors that lead to in-depth exploration of a problem.
NCTM Standards: Standards-Based Curriculum and Impact on Student Success

While teachers can play an important role in reducing the level of mathematics anxiety in their students, researchers continue to emphasize the need to reform teacher education to promote a corresponding transformation in mathematics instruction in today's schools. Most often, current teaching practices in mathematics classrooms do not provide sufficient critical thought needed to compete in an ever advancing technological age. Research conducted by the Board of Directors of the National Council of Teachers of Mathematics (NCTM) in the mid-1980s indicated that the mathematics curricula for elementary and secondary schools in the United States were not as effective as it could be. NCTM's response to the need for change was the publication of Curriculum and Evaluation Standards for School Mathematics (Standards) in 1989. The NCTM suggested that standards would improve nationwide test scores in the area of mathematics.

Even after the publication of the Standards in 1989, students continue to face the same problems in classrooms. When presented with math problems, some students find themselves anxious, distracted, and sweaty palmed (Tobias, 1993). Pejouhy (1990) and Proga (2005) advocated the implementation of the NCTM Standards to impact and reduce the level of math anxiety students currently feel, compared with more traditional approaches to teaching mathematics. Pejouhy, however, found that math teachers tend to be resistant to making changes in the math curriculum recommended by the NCTM. Often, teachers tend to teach the way they were taught. Sarason (1993) maintained that any reform in education must first begin with teacher training. The preservice and continuing education of teachers of mathematics should provide teachers with opportunities to examine and revise assumptions about how mathematics should be taught and how students learn mathematics (NCTM, 1989, 1991, 1995b).

However, the NCTM Standards were established as a broad framework to guide reform in school mathematics (NCTM, 1989 and 2000), not as a specific mathematics curriculum. The NCTM's vision includes mathematics teachers encouraging students, probing for ideas, and carefully judging the maturity of a student's thoughts and expressions (NCTM, 1989). The NCTM (1989, 2000, and 2006) contended that when the learning of math is made relevant, students will find the subject more useful and will be less likely to fear it. As suggested by the Standards, teachers should emphasize hands-on manipulatives, group work, math games, dailylife applications, and computer and calculator usage. In 1995, the NCTM published a supplemental brochure of broadly defined educational practices intended to help prevent math anxiety (1995a): 
$\checkmark$ accommodate different learning styles;

$\checkmark$ create a variety of testing environments;

$\checkmark$ design the experience in the math class so that students feel positive about themselves;

$\checkmark$ remove the importance of ego from classroom practice;

$\checkmark$ emphasize that everyone makes mistakes in mathematics;

$\checkmark$ make math relevant;

$\checkmark$ empower students by allowing them to have some input into their own evaluations;

$\checkmark$ allow for different social approaches to learning mathematics;

$\checkmark$ emphasize the importance of original, quality thinking rather than the rote manipulation of formulas; and

$\checkmark$ characterize math as a buman endeavor

Clearly, mathematics anxiety is not the sole reason for low math achievement in this country; nevertheless, it is a critical academic problem, and educators should be informed of its nature as well as of its solutions. Educators also need to examine specific teaching strategies that will draw from the NCTM standards and be effective in overcoming students' math anxiety. Of particular interest to this paper is to tease apart how mastery and performance goals relate to the construct of math anxiety and how a teachers' understanding of creating mastery-oriented classrooms can help to prevent or reduce the anxiety students experience during mathematics. The goal theory literature is particularly appropriate given the common themes presented in the math anxiety literature and the NCTM Standards. Student concerns over ability versus effort, an emphasis on quality of thinking over rote memorization, enhancing the perceived meaning and relevance in mathematic tasks, understanding student perceptions of the meaning behind making mistakes, and examining the nature of evaluation and assessment all have direct relevance to the current research examining students' achievement goals.

\section{Achievement Goals}

\section{Definition and Associated Behaviors}

Students' goal orientations have proven to be influential on their employment of beneficial academic behaviors (Ames, 1984; Ames \& Archer, 1988; Archer, 1994; Dweck, 1986; Dweck \& Leggett, 1988; Hagen \& Weinstein, 1995; Meece, Blumenfeld,\& Hoyle, 1988; Pintrich \& Garcia, 1991; Stipek \& Kowalski, 1989). Students with mastery goals are interested in learning new skills and improving their understanding and competence, whereas students with performance goals are more concerned with proving their ability or avoiding negative judgments of their competence (Ames \& Archer, 1988; Dweck \& Leggett, 1988). Early investigations in this area led researchers (Dweck, 1986; Dweck \& Leggett, 1988) to conclude that when students adopt mastery goals they seek out challenge, persist in the face of difficulty, view errors as opportunities to learn, and are more likely to be intrinsically motivated. In contrast, the adoption of performance goals left students vulnerable to a more 'helpless' motivational pattern involving the avoidance of challenging tasks, less intrinsic motivation, and viewing errors as indicative of failure.

More recent developments in the goal theory literature have expanded this goal framework by adding the approach and avoidance designation to the masteryperformance dichotomy. First, there was an expansion to a trichotomous framework that distinguished between two types of performance goals: a performance approach goal and a performance-avoidance goal (Church, Elliot, \& Gable, 2001; Elliot \& Church, 1997; Elliot \& Harackiewicz, 1996; Middleton \& Midgely, 1997; Rawsthorne \& Elliot, 1999). Students adopting performance goals may be motivated to outperform others (performance-approach) or motivated to avoid failure (performance-avoidance). In this trichotomous framework, mastery goals have been related to intrinsic motivation, academic efficacy, self-regulated learning, deep processing, persistence and effort, help-seeking behavior, viewing learning tasks as a challenge and negatively predict test anxiety; performance-approach goals have sometimes been positively linked to class grades and exam performance, grade aspirations, effort and persistence while studying, effective strategy use, intrinsic motivation, and viewing learning tasks as a challenge, yet other times have been related to avoidance of help-seeking behaviors, shallow or surface processing of information, and fear of failure and test anxiety (particularly in achievement situations that are perceived as a threat rather than an opportunity for challenge with little chance of failure); and performanceavoidance goals have been related to test anxiety, fear of failure, disorganized studying, surface processing, ineffective strategy use, procrastination, viewing learning tasks as a threat, and negatively related to class grades and exam performance, task persistence, intrinsic motivation, help-seeking, self-regulated learning, deep processing and academic efficacy (Cury, Elliot, Sarrazin, Da Fonseca, \& Rufo, 2002; Elliot, 1999; Elliot \& Church, 1997; Elliot \& Harackiewicz, 1996; Elliot, McGregor \& Gable, 1999; McGregor \& Elliot, 2002; Middleton \& Midgley, 1997; Rawsthorne \& Elliot, 1999; Shih, 2005). Even when the effects of students' personal goal orientations were controlled for, perceived classroom emphasis on mastery goal positively related to students' help seeking while perceived classroom emphasis on performance-avoidance and performanceapproach goals positively related to help-seeking avoidance (Karabenick, 2004). Given these overall findings, it has been proposed that it is the performance-avoidance goals that hold the most 
disadvantage for students' learning (Elliot \& Church, 1997; Elliot \& Harackiewicz, 1996; Rawsthorne \& Elliot, 1999).

Most recently, the goal framework was fully expanded to the $2 \times 2$ model that also includes both the mastery-approach and mastery-avoidance designations. Students adopting mastery-approach goals will be positively motivated to master a task and advance one's learning; students adopting mastery-avoidance goals will be negatively motivated to avoid misunderstanding and leaving a task un-mastered. Traditionally, the mastery goal has been associated with positive processes (see above paragraphs), but the avoidance component is related to more negative outcomes; mastery-avoidance goals may be more likely to be adopted by individuals who have low competence perceptions and a fear of failing at the task (Elliot, 1999).

In a validation study of this newest $2 \times 2$ achievement goal framework, the pattern for masteryavoidance goals was more negative than that for mastery-approach goals but more positive than for performance-avoidance goals (Elliot \& McGregor, 2001). This study demonstrated that both masteryavoidance and performance-avoidance goals are linked with the antecedents of fear of failure (tendency to experience apprehension or anxiety in evaluative situations because failure is linked to aversive outcomes) and low self-determination, and consequences for individuals having these goals included disorganized studying, anticipatory test anxiety, and the 'worry' and 'emotionality' subscales of test anxiety. (The 'worry' subcomponent of test anxiety focuses on concerns about not being able to answer math test items and the 'emotionality' subcomponent is a measure of students' nervousness for the task.) However, mastery-avoidance goals resulted in some positive qualities including individuals later adopting both mastery-approach and performance-approach goals, and performanceavoidance goals were the only goals to be negative predictors of achievement on exams and positive predictors of health center visits for illness. "Performance-avoidance goals appear to be the primary regulatory vulnerability in achievement settings" (Elliot \& McGregor, 2001, pg. 516). Later research by Elliot and colleagues further examined fear of failure and its relationship to achievement goals (Conroy \& Elliot, 2004). A general fear of failure positively predicted mastery-avoidance and performance-avoidance goals, and it was a weaker predictor of performance-approach goals. In particular, both avoidance goals were strongly related to fears of experiencing shame and embarrassment. Of special note is the direction of influence uncovered in this study, it is the fear of failure that biases students toward the avoidant achievement goals.
Later research has continued to discuss the relative merits of each of the four goal constructs: while mastery-approach goals are related to deep processing, intrinsic motivation, and GPA; mastery-avoidance goals are related to disorganized studying and test anxiety; performance-approach goals are linked to surface-level processing; and performance-avoidance goals are positively linked to test anxiety and negatively linked to intrinsic motivation, exam performance, and GPA (Conroy \& Elliot, 2004; Finney, Pieper, \& Barron, 2004). Performance-avoidance goals have been consistently linked to test anxiety, and that anxiety (particularly its worry component) can undermine exam performance (Ryan et al., 2007). However, some research findings report that mastery-avoidance goals are linked to cognitive anxiety and fear of failure, and suggest "that the emotional cost from adopting masteryavoidance goals may be great and may be even more substantial compared to the adoption of performanceavoidance goals, for which there is ample evidence regarding their deleterious effects for achievement and affect" (Sideridis, 2008, pg. 66).

Clearly the $2 \times 2$ goal framework is still in its formative stages in the goal theory literature, and future work in this area will tease apart associated behaviors and outcomes for students adopting each of the four goal constructs. Of particular interest to this paper is to tease apart how each of the goal constructs relates to the construct of math anxiety specifically.

\section{Achievement Goals and Math Anxiety}

Studies have begun to tease apart the link between the goals student adopt and their math anxiety. However, investigations that have looked at the relationships of all four goal constructs with student's math anxiety are only just beginning. Bong (2009) reported that elementary and middle- students with performance-approach, mastery-avoidance and performance-avoidance goals experienced more math anxiety (with the mastery-avoidance goal showing the strongest relationship with math anxiety). While mastery-approach goals appeared to be particularly beneficial, providing a stronger 'psychological armor', in combating adolescents' help-seeking avoidance and test anxiety in math classes (particularly those confronted with competitive, ability-focused learning environments).

Putwain \& Daniels (2010) examined how the relationships between test anxiety and competency beliefs are moderated by achievement goals among secondary mathematic students in England (ages between 11 and 12 years). Surprisingly, weak to moderate positive correlations were found between the test anxiety subscales of 'thoughts' (worrisome thoughts about a negative outcome for tasks) and 'autonomic 
reaction' (such as shaky hands during test-taking) and all four achievement goals, although the effects were slightly stronger for both avoidance goals. Further, students with low competency beliefs in math reported more worrisome thoughts when they had adopted a mastery-avoidance goal.

While not including all four goal dimensions in their analyses, other studies have also examined the relationship between students' math anxiety and achievement goals using the earlier trichotomous framework (mastery goal and two performance goals). Sixth and eighth-grade Norwegian students' adoption of performance-avoidance or performance-approach goals was predictive of the 'emotionality' dimension of math anxiety which captures how nervous or tense students might feel during math lessons (Skaalvik, 1997). What is of particular note is that these relationships existed independent of students' perceived abilities. Middleton \& Midgley (1997) found a similar pattern of results with sixth-grade students where performance-avoidance and performance-approach goals were a predictor of test anxiety in math (particularly the 'worry' subcomponent of test anxiety that focuses on concerns about not being able to answer math test items and evaluating how well one's peers might be doing); however this relationship was stronger for the performance-avoidance goals which were also negatively related to help-seeking behavior.

Zusho, Pintrich, and Cortina (2005) examined the relationships between the trichotomous framework of achievement goals and undergraduate students' motivational outcomes on math tasks. Anxiety was defined as the feeling of nervousness and tenseness a student experienced before, during, and after a math task. Performance-avoidance goals were related to lower achievement scores, lower levels of competence and higher levels of anxiety while mastery and performance-approach goals had positive outcomes for students' interest and competence perceptions. These findings led researchers to conclude there is "not one specific path to academic success" and to reinforce the advantages of adopting multiple goals (mastery and performance-approach goals) for students' motivation and achievement (pg. 155).

Other research, focused on only the mastery and performance-approach distinction, has also investigated how classroom goal conditions and students' personal goals interact in their influence on students' motivation for math tasks. Linnenbrink (2005) found that $5^{\text {th }}$ and $6^{\text {th }}$ grade students' mastery goals were unrelated to test anxiety in math while performance-approach goals were positively related to test anxiety in math. However, while the pattern of outcomes for students' personal goals supports the mastery goal perspective, the classroom goal condition supported the multiple goal perspective. The combined classroom condition (mastery and performance-approach goals) had the most beneficial pattern on students' achievement and helpseeking. The effect of classroom goal structures did not vary based on students' personal goals. However, the inclusion of a performance-avoidance dimension would provide a better picture of how personal and classroom achievement goals interact in their influence on students' motivational outcomes.

Lau \& Nie (2008) extended Linnenbrink's (2005) study by using the trichotomous framework and looking at how the classroom goal structure and students' personal goals impact other important motivational behaviors in math (although these researchers did not include anxiety as an outcome variable). Mastery goals were correlated with math achievement, engagement, and interest math, while being negatively related to effort withdrawal and avoidance; performanceavoidance goals were negatively related to achievement and engagement and positively related to effort withdrawal and avoidance; while the evidence for relationships between performance-approach goals and outcomes were inconclusive. Math classrooms that emphasize mastery goals highlighting learning and improvement led to increased student achievement and less withdrawal when math work was difficult or boring. In contrast, math classrooms that emphasize performance goals highlighting social comparisons of performance and competition negatively impacted students' achievement and engagement in math activities, and students were less likely to be engaged and more likely to withhold effort and give up in the face of difficulty. In fact, these researchers report that classroom performance goal structures can exacerbate maladaptive outcomes for those students who already hold personal performance-avoidance goals, while classroom mastery goals and students' personal mastery goals can operate in an additive way to promote positive motivational patterns during students' math experiences.

Existing research investigating the relationships between students' achievement goals and reported math anxiety clearly points to the benefits of students adopting mastery-approach goals (as does the achievement goal literature more generally examining the effects of goals for various achievement-related behaviors). In addition, the culmination of this research also points out the particularly deleterious effects of students adopting performance-avoidance goals. A bit more inconclusive, and worthy of further study, are the effects of students adopting the performance-approach and mastery-avoidance goals. In the meantime, the classroom implications for this line of research are clear. Educators should take steps to encourage mastery-approach goals in students and to create a learning environment that emphasizes these goals in their classrooms. 


\section{Overcoming Math Anxiety through Mastery- Approach Goals}

Research indicates that classroom practices can influence the goals students adopt (Ames, 1990; Ames \& Archer, 1988; Anderman, 1997; Anderman \& Young, 1994; Maehr \& Anderman, 1993; Meece, 1991; Meece \& Miller, 1999; Midgley, Anderman \& Hicks, 1995; Urdan, 1997), and educators should strive to create masteryoriented classrooms (Bong, 2009; Karabenick, 2004; Lau \& Nie, 2008; Maehr \& Anderman, 1993; Midgley, Anderman \& Hicks, 1995). Even when some performance cues are present, the overriding classroom goal structure can influence positive motivational patterns when mastery goals are made salient (Ames \& Archer, 1988). The main idea here is to really impress upon students the importance of striving toward learning, growth and improvement not just goals related to the societal pressures of achieving ideal grades and getting accepted to top colleges. The preoccupation with how one is perceived by others is predictive of anxiety, and educators need to reduce the attention paid to social comparisons in order to create effective learning environments (Karabenick, 2004; Skaalvik, 1997). When teachers make performance goals salient, students have a tendency to focus on their ability, evaluate their ability negatively, and attribute their lack of ability as a cause for failure (Ames \& Archer, 1988).

When teachers emphasize mastery approach goals the norms and values in the learning environment encourage students' on-task behavior and discourage their anxiety and disruptive behavior (the latter of which may be a means for protecting students' self-worth), foster long-term learning strategy usage, help students to create realistic and challenging goals, and instill a belief that effort is tied to success (Ames \& Archer, 1988; Kaplan, Gheen, and Midgley, 2002). In addition, when mastery goals are made salient in the classroom, students are more likely to use effective learning strategies, seek out challenge, and see that effort goes hand in hand with success, all of which may help to override the negative impact of students' with low perceived ability (Ames \& Archer, 1988). A need for a change in classroom goal structure is particularly pronounced in the middle schools where some adolescents may face a turning point in patterns of motivation and achievement, and where teachers may be more prone to create performance-focused school cultures than teachers in the elementary schools (Maehr \& Anderman, 1993; Midgley, Anderman, \& Hicks, 1995).

Pioneering work in the goal theory literature gives teachers a pretty good picture of what it takes to create a mastery-oriented classroom. The instructional strategies supporting a mastery oriented classroom structure can be organized across these main areas: tasks, authority, evaluation and recognition, and classroom climate (Ames, 1992; Stipek, 1998). Many of the core instructional principles presented during this discussion are alluded to in the NCTM professional assessment standards supplemental brochure to address math anxiety (1995a) presented earlier in this manuscript. Student concerns over ability versus effort, an emphasis on quality of thinking over rote memorization, enhancing the perceived meaning and relevance in mathematic tasks, understanding student perceptions of the meaning behind making mistakes, and examining the nature of evaluation and assessment all have direct relevance to research examining students' achievement goals and underscore how a teachers' understanding of creating mastery-oriented classrooms can help to prevent or reduce the anxiety students experience during mathematics. (Also see Appendix B for a summary of suggestions.)

\section{Tasks}

Teachers should engage students in tasks that involve variety and reasonable challenge, emphasize the goals of understanding and improvement (rather than memorization), capitalize on student interest and the intrinsic value of learning, and convey the activity's perceived meaning and real-world significance (Ames, 1992; Meece \& Miller, 1999; Patrick et al., 2001; Stipek, 1998). Instructional activities should emphasize mastering content and acquiring important academic skills and also be perceived as interesting and important to students. Teachers might allow for some student choice in topics and integrate students' experiences into lesson discussions. Research on authentic instruction has demonstrated that student learning benefits from the use of authentic tasks which essentially embed reallife context into school-related activities such as writing (Jago, 2002), science (Kumar \& Voldrick 1994) and mathematics (Kramarski, Mevarech, \& Arami, 2002). Use of out-of-school contexts (such as zoos, planetariums, museums, or botanical gardens) and information technology (internet and virtual world 'field trips') may lead to instruction that is more valid, authentic, and motivating (Braund \& Reiss, 2006). Students engaged in authentic research assignments connected to their own interests might interview school staff, parents or subject matter experts in the community and then create multi-modal products appropriate to the project that includes oral presentations, written reports, or portfolios (Krovetz, Casterson, McKowen \& Willis, 1993; Schack, 1993). These suggestions pertaining to the nature of the tasks students are asked to engage in also parallel recommendations for preventing math anxiety in particular. Building on materials published by the NCTM's 2000 Principles and Standards for School 
Mathematics, Furner and Duffy (2002) recommended that teachers make math relevant to students in order to prevent math anxiety and highlight the importance of emphasizing original, quality thinking over the rote memorization of mathematic formulas. They suggest that math teachers assess students' mathematical disposition regarding both their interest and curiosity in doing math, their willingness to persevere in math tasks, and their appreciation for mathematics' real-life application and connection to other disciplines. Eddy (1985) and Sherard (1981) discussed research-based techniques for reducing mathematics anxiety that included making students aware of the daily use of mathematics and helping to develop students' selfconfidence and problem-solving in math activities. Lane (1999) refers to the Japanese model of math instruction where teachers pose problems students have never seen before and they make connections from what they know to solve and develop skills; the Japanese possess a resilience toward solving problems and not giving up, the kind of group think and problem solving that typifies the Japanese approach to learning math is also important in the advancement of technology and the sciences.

Teachers should also engage students in tasks that encourage active involvement and cooperative learning activities (Meece \& Miller, 1999; Patrick et al., 2001; Stipek, 1998). Tasks should require active student involvement and participation in substantive and meaningful learning activities, and allow for some degree of surprise and originality. Students should be encouraged to collaborate on learning tasks during effectively planned cooperative learning where students are held individually accountable for their learning and group participation. Teachers can ensure individual accountability through various means: have students each take on some identifiable part of a group project (for instance writing one section of a research paper or being part of the presenting team), test students individually and contribute individual improvement points to a team score, or have students choose individual roles within the groups (for instance the role of group spokesperson, note-taker, conflict mediator or artist). In cooperative learning, students are encouraged to work together on common goals, capitalize on each others' strengths and experiences to master academic material, and learn to collaborate with students from different backgrounds. By working in groups of mixed ability, students have the ability to scaffold each other's understanding during peer-mediated learning. There are a host of beneficial outcomes for students when cooperative learning is used effectively: academic achievement, higher-level reasoning and problemsolving skills, active learning and time-on-task, selfesteem, interpersonal skills and inter-group relations, and positive attitudes towards school (Aronson, Blaney,
Stephan, Sikes \& Snapp, 1978; Jacob, 1999; Johnson, Johnson \& Smith, 1995; Schrenko, 1994; Slavin, 1991; 1995; Vermette, 1998). The use of cooperative learning can be very valuable to the math anxious learner. When students are placed in groups and solving math problems together cooperatively, not in isolation, students can collaborate and do the solving of math together in a less threatening environment where they have each other to lean on for support; hence lessening the level of anxiety that can come into play. Cooperative learning is a key strategy in teaching mathematics in today's classrooms (NCTM, 2000). See Appendix A for a summary of resources.

\section{Authority}

The degree to which educators involve children in academic decision-making can have a positive impact on students' motivation (Ames, 1992; Stipek, 1998). Teachers might allow for opportunities for students to develop responsibility and independence by engaging students in establishing the methods and pace of their learning, and developing self-regulatory and self-directed learning strategies. Skilled self-regulated learners tend to have a mastery goal orientation, high sense of selfefficacy, report greater intrinsic interest in learning, are able to concentrate on their learning, attribute poor performance to controllable areas like strategy use and insufficient practice, and systematically adapt their learning approach based on self-monitoring of their goals (Zimmerman, 1998). Teachers can encourage students' self-regulation skills by communicating the advantages of using self-regulated strategies; demonstrating specific strategies like goal-setting, monitoring and self-assessment; integrating opportunities for self-regulated learning into curriculum; offering opportunities for self-regulated learning in social contexts where peers can model effective selfregulatory skills; enlisting the help of parents in promoting students' self-regulatory skills; and generally having patience while remaining persistent in their encouragement of students' self-regulation (Paris \& Paris, 2001; Perry, VandeKamp, Mercer, \& Nordby, 2002; Pressley, 1995; Schunk \& Zimmerman, 1997; Zimmerman, Bonner, \& Kovach, 1996).

"The perception of control appears to be a significant factor affecting children's engagement in learning and quality of learning" (Ames, 1992, pg. 266). Students can be afforded some choice in their chosen focus of an assignment (Stipek, 1998). For example, during a unit on great mathematical thinkers, students might be given the choice of which individual to research and present on. Students might even get to choose the nature of their final product and whether they demonstrate their mastery through a written summary report, personal reaction paper, visual chart or 
concept map, or PowerPoint display. Whichever the final product students might create, teachers would assist students in creating goals that will facilitate their learning endeavors. Teachers can involve students in personal goal-setting with specific and challenging goals and encourage students to engage in self-evaluation of their own improvement and mastery using preestablished rubrics, guiding questions or checklists, or simple answer keys (Ames, 1992; Stipek, 1998). In particular, goals are most likely to benefit learning and motivation when they are specific, proximal, and challenging while still being perceived as realistically attainable (Locke \& Latham, 2002; Schunk, 1990; Schunk, 2001). Then, teachers can provide one-on-one feedback that helps student assess their progress, provides encouragement, and offers specific ideas for how they might continue to improve through the use of more effective learning strategies or academic resources. Work from Arem (2003) and Tobias (1993) shows that students need to be actively involved in self-regulating their feelings toward math and how they learn it. They need to know when anxiety arises and what to do to manage it. It is important that students set goals in the math classroom each year and that teachers collect data using surveys to assess their students' levels of math anxiety. Students should be encouraged to realize and accept their feelings toward math, yet also set goals to help in managing them.

\section{Evaluation}

In a mastery goal classroom, success is defined by improvement, value is placed on effort and the process of learning, satisfaction is gained from working hard and learning something new, and evaluation is private (Ames, 1992; Ames \& Archer, 1988). Of course, grading will always play a part in education, but it is how grades are used and the nature of grading that is emphasized that plays a key role in influencing students' motivational outlooks. Making continual comparisons to classmates and consistently grading on a curve can create a competitive classroom environment and lead students to focus on performance goals rather than on the more important goals of learning and understanding. The potentially negative impact of grades can be offset when teachers base grading as much as possible on effort, improvement and the attainment of important pre-defined standards rather than normative comparisons (Stipek, 1998). When we de-emphasize normative comparisons, where student performance is expected to fall in the classic bell-shaped normal distribution, and instead evaluate students against preset criteria, all students have the opportunity to achieve top scores. Teachers should use evaluation opportunities to highlight a student's individual progress rather than how they scored relative to the rest of their classmates. Teachers might emphasize the information conveyed in the grade whether it is attainment of a personal goal or the need for improvement. In this context, what is highlighted is the opportunity for students to receive informative feedback showing how far their understanding and skills have progressed or where greater effort may be warranted. Teachers will want to de-emphasize using social comparison in their evaluation and assessment of students in other ways as well (including use of public charts of students' progress, displays of selected papers and achievements, or ability grouping), because when teachers highlight grading and public evaluation students becomes focused on their ability and the range of ability demonstrated by their peers in the classroom (Ames, 1992). Student evaluation should be private, emphasize an individual's progress in learning, and be accompanied with opportunities to improve.

Teachers might even use alternative forms of assessment, including portfolios or performance assessments, so students can experience a range of ways to demonstrate their mastery on subject matter (rather than over-relying on one type of assessment). When we reduce students' fear of failure we make one step towards minimizing students' tendency to adopt performance-avoidance goals (Elliot \& Church, 1997). An eclectic approach to testing, that employs less timed and paper-and-pencil testing and more varied forms of assessment in mathematics instruction, appears to be the means for enlisting students' diverse styles of learning and thinking as well as reducing math anxiety for many students (Furner \& Duffy, 2002). Alternative forms of assessment might include journal writing, selfreflections, and portfolios. By considering these alternatives during their mathematic assessment, teachers can create a variety of testing environments and remove the importance of ego from the classroom as outlined in the NCTM standards intended to reduce students' math anxiety (1995a).

And while extrinsic rewards have their place in the classroom, teachers would be well-served to examine how they are employed. The public use of rewards can make students' ability salient; but when made contingent on students' effort and goal accomplishments, rewards can enhance achievement-related behaviors (Ames, 1992). Teachers should consider using tangible rewards infrequently, only when necessary to encourage student engagement, and make them contingent on the quality of work (Stipek, 1998). Teachers might even consider recognition for a student's exemplary individual improvement or the achievement of their own 'personal best' rather than just rewarding the best score or project.

"The goal is to create an instructional program that capitalizes on students' intrinsic desires to learn, that focuses their attention on understanding and mastery, and that fosters academic values. This does not mean 
that extrinsic rewards have no place in the classroom...The practical task, therefore, is how to create a context in which a focus on learning and understanding prevails and in which extrinsic rewards and concerns about performance do not undermine intrinsic motivation and attention to understanding and mastery." (Stipek, 1998, pg. 162)

\section{Classroom Climate}

Ultimately, teachers should create a classroom climate that helps students to feel they can take risks, make mistakes, and reveal their lack of understanding (Stipek, 1998). Student should feel comfortable asking questions in their pursuit to understand class material and master important academic skills. Teachers should encourage students to ask questions when they do not understand and highlight the fact that asking questions and turning to helpful resources like our teachers and textbooks are the hallmarks of being a strong learner. Inevitably, we all make mistakes when we are learning something new. Students should understand that errors are simply a natural part of the learning process (Ames, 1992; Ames \& Archer, 1988). Errors convey important information about where students should revise work to correct misunderstandings and increase personal mastery and understanding. Instead of emphasizing a mistake as 'incorrect' or as an 'error', teachers can utilize indirect strategies that center students' attention on the source of the difficulty, offer hints or cues to help students overcome the difficulty, and then give students a second chance at the task (Stipek, 1998). In particular to the teaching of mathematics, it has been recommended that teachers convey to students that everyone makes mistakes during math tasks and that students should not feel inadequate or ashamed when they fail to understand mathematic concepts (Furner \& Duffy, 2002; Turner, Midgley, Meyer, Gheen, Anderman, \& Kang, 2002). This belief that mistakes are a natural part of mathematics learning is also outlined in the NCTM standards for reducing students' math anxiety (1995a). By modeling their own thinking processes, educators can demonstrate that being unsure, learning from mistakes, and asking questions are a natural and necessary part of learning (Turner et al., 2002).

Overall, the classroom should be perceived as a community of learners where students treat one another with respect and engage in constructive relationships that promote student motivation and ability to engage in the academic work of the classroom. Mastery-oriented teachers exhibit support and concern for students' progress as well as their physical and emotional comfort (Patrick et al., 2001). Teachers want to create a classroom atmosphere where students think of their peers as helpful resources in their pursuit of learning and understanding rather than as potential competitors for a limited pool of top scores or teacher accolades. Effectively designed evaluation and assessment strategies that downplay social comparisons are one important step in reducing competition in the classroom. Cooperative learning, mentioned in earlier paragraphs will also help to create this community of learners. Cooperative learning has been reported to result in students who have improved attitudes towards school, teachers, academic tasks, and their peers (Aronson, Blaney, Stephan, Sikes \& Snapp, 1978; Jacob, 1999; Johnson \& Johnson, 1995; Slavin, 1991, 1995).

Research focusing on overcoming mathematic anxiety echoes this emphasis on examining the classroom climate. Posamentier, Smith, Stepelman (2009) maintained that math teachers must see to it that no pupil becomes incapacitated and immobilized with fear. Although there is no simple formula for teachers to aid their students in overcoming excessive math anxiety, there are some things all teachers can do to provide a positive experience for students when taking a math course: relax and enjoy, hence, teachers should be comfortable with the mathematics they are teaching as well as with their classes; curb excessive competitiveness; do not use speed tests; praise students' efforts; never humiliate students; develop a sense of humor; be a positive role model; do not use math as a punishment; teach how to read mathematics; treat boys, girls, and minorities equally; help students to develop spatial relations; have students make up their own problems; and lastly, humanize mathematics (Posamentier, Smith \& Stepelman, 2009).

\section{CONCLUSION}

So, what should teachers really be doing to help children when teaching mathematics? Although math anxiety remains a perplexing, persistent, and only a partially understood problem from which many people suffer, if math teachers do something about helping students develop their confidence and ability to do math it can impact greatly the lives of their students. The NCTM (1991) indicated that "classrooms should be mathematics communities that thrive on conjecturing, inventing, and problem solving, and that build mathematical confidence" (p. 6). Research in this article suggests that teachers can play an active role in both helping to prevent and reduce mathematics anxiety in their students. Classroom practices can influence the goals students adopt, and educators should strive to create mastery-oriented classrooms by examining the nature of the tasks they assign students, the authority or degree they involve students in academic decisionmaking, the types of evaluation and recognition they utilize, and the classroom climate they create. It may be favorable to the students if less of an emphasis is placed 
on test taking and competition, passing or failing, and winning or losing. Students with mastery goals are interested in learning new skills and improving their understanding and competence; they are engaged in the process, not focused on the product. They are taking responsibility for their learning and engaged in activities that allow for self-regulation and self-direction. Their success is defined by individual improvement, they place value on effort, and their satisfaction is gained from working hard and learning something new. And they thrive in a classroom climate that helps students to feel they can take risks, make mistakes, and reveal their lack of understanding and seek help during their internal drive towards growth and personal mastery. Epitomizing this motivational approach, Ruedy and Nirenberg (1990, p. 61) recounted a poem by the Chinese sage, Chuang Tzu, from thousands of years ago:

\section{The Need to Win}

When an archer is shooting for nothing

He has all his skill.

If he shoots for a brass buckle

He is already nervous.

If he shoots for a prize of gold

He goes blind

Or sees two targets-

He goes out of his mind!

His skill has not changed. But the prize

Divides him. He cares.

He thinks more of winning

Than of shooting-

And the need to win

Drains him of power. (p. 61)

\section{REFERENCES}

Alexander, L., \& Martray, C. (1989). The development of an abbreviated version of the mathematics anxiety rating scale. Measurement and Evaluation in Counseling and Development, 22, 143-150.

Alexander, L., \& Cobb, R. (1984, November). Identification of the dimensions and predictors of math anxiety among college students. Paper presented at the Annual Meeting of the Mid-South Educational Research Association, New Orleans, LA. (ERIC Document Reproduction Service No. ED 251 320)

American Association of University Women. (1992). How schools shortchange girls. Washington, DC: American Association of University Women Educational Foundation.

Ames, C. (1984). Achievement attributions and selfinstructions under competitive and individualistic goal structures. Journal of Educational Psychology, 76, 478-487.

Ames, C. (1990, April). The relationship of achievement goals to student motivation in classroom settings. Paper presented at the meeting of the American Educational Research Association, Boston.
Ames, C. (1992). Classrooms: Goals, structures, and student motivation. Journal of Educational Psychology, 84(3), 261271.

Ames, C., \& Archer, J. (1988). Achievement goals in the classroom: Students' learning strategies and motivation processes. Journal of Educational Psychology, 80(3), 260-267.

Anderman, E.M. (1997). Motivation and school reform. In M.L. Maehr and P.R. Pintrich's (Eds.), Advances in Motivation and Achievement, Vol. 10: (pp. 303-337). Greenwich, CT: JAI Press.

Anderman, E.M. \& Young, A.J. (1994). Motivation and strategy use in science: Individual differences and classroom effects. Journal of Research in Science Teaching, 31, 811-831.

Anton, W. D., \& Klisch, M. C. (1995). Perspectives on mathematics anxiety and test anxiety.In C. D. Spielberger, \& P. Vagg (Eds.), Test anxiety. Washington, DC: Taylor \& Francis Publishers.

Archer, J. (1994). Achievement goals as a measure of motivation in university students. Contemporary Educational Psychology, 19, 430-446.

Arem, C. A. (2003). Conquering math anxiety. 2 $2^{\text {nd }}$ Edition. Pacific Grove, CA: Brooks/Cole.

Aronson, E., Blaney, N., Stephan, C., Sikes, J., \& Snapp, M. (1978). The jigsaw classroom. Beverly Hills, CA: Sage.

Bernstein, J. D. (1992). Barriers to women entering the workforce: Math anxiety. NewJersey Equity Research Bulletin No. 3.

Boaler, J. (2008). What's math got to do with it? Helping children learn to love their least favorite subject--and why it's important for America. New York, NY: Penguin Group (USA) Inc.

Bong, M. (2009). Age-related differences in achievement goal differentiation. Journal of Educational Psychology, 101(4), 879-896.

Braund, M. \& Reiss, M. (2006). Towards a more authentic science curriculum: The contribution of out-of-school learning. International Journal of Science Education, 28(12), 1373-1388.

Brush, L. R. (1981). Some thoughts for teachers on mathematics anxiety. Arithmetic Teacher, 29(4), 37-39.

Burns, M. (1998). Math: Facing an American phobia. Sausalito, CA: Math Solutions Publications.

Buxton, L. (1991). Math panic. Portsmouth, NH:Heinemann.

Church, M. A., Elliot, A. J., \& Gable, S. L. (2001). Perceptions of classroom environment, achievement goals, and achievement outcomes. Journal of Educational Psychology, 93, 43-54.

Conroy, D.E. \& Elliot, A.J. (2004). Fear of failure and achievement goals in sport: Addressing the issue of the chicken and the egg. Anxiety, Stress, and Coping, 17(3), 271-285.

Crawford, C. G. (1980). Math without fear. New York: New Visionpoints/Vision Books.

Cury, F., Elliot, A., Sarrazin, P., Da Fonseca, D., \& Rufo, M. (2002). The trichotomous achievement goal model and intrinsic motivation: A sequential meditational analysis. Journal of Experimental Social Psychology, 38, 473-481.

Dawson, R. (n.d.). Setting the record straight on H1 visa legislation. An Opinion Piece by the Information Technology Industry Council. Retrieved on July 20, 2007 at http://www.itic.org/policy/h1b_000628.html 
Conroy, D.E. \& Elliot, A.J. (2004). Fear of failure and achievement goals in sport: Addressing the issue of the chicken and the egg. Anxiety, Stress, and Coping, 17(3), 271-285.

Dweck, C. S. (1986). Motivational processes affectinglearning. American Psychologist, 41, 1040-1048.

Dweck, C.S., \& Leggett, E.L. (1988). A social-cognitive approach to motivation and personality. Psychological Review, 95(2), 256-273.

Eddy, L. (1985). The nature and treatment of mathematics anxiety. Requirements for course S591--Exit Project, Indiana University. (ERIC Document Reproduction Service No. ED 277 595)

Elliot, A.J. (1999). Approach and avoidance motivation and achievement goals. Educational Psychologist, 34(3), 169189.

Elliot, A. J., \& Church, M. A. (1997). A hierarchical model of approach and avoidance achievement motivation. Journal of Personality and Social Psychology, 72, 281-232.

Elliot, A. J., \& Harackiewicz, J. M. (1996). Approach and avoidance achievement goals and intrinsic motivation: A mediational analysis. Journal of Personality and Social Psychology,70, 461-475.

Elliot, A.J. \& McGregor, H.A. (2001). A 2 x 2 achievement goal framework. Journal of Personality and Social Psychology, 80(3), 501-519.

Elliot, A.J. McGregor, H.A, and Gable, S. (1999). Achievement goals, study strategies, and exam performance: A mediational analysis. Journal of Educational Psychology, 91(3), 549-563.

Elliot, P. (1983). Question: Is math anxiety a figment of the imagination? Answer: Never! (A neurological glimpse at mathematics anxiety). International Journal of Mathematics Education in Science and Technology,_14, 777-784.

Finney, S.J., Pieper, S.L. \& Barron, K.E. (2004). Examining the psychometric properties of the achievement goal questionnaire in a general academic context. Educational and Psychological Measurement, 64(2), 365-382.

Furner, J. M. \& Duffy, M.L. (2002). Equity for all students in the new millennium: Disabling math anxiety. Intervention in School and Clinic, 38(2), 67-74.

Gallup, G. H. (2005). Math Problematic for U.S. Teens: Youth Survey Poll, Retrieved on Novermber 16, 2010 at: http://www.gallup.com/poll/16360/mathproblematic-us-teens.aspx

Gerig, D. L. (1988). Sex differences in mathematics achievement: What are they and why do they exist? Master's Project, Indiana University at South Bend. (ERIC Document Reproduction Service No. ED 296 907)

Goldberg, M., \& Harvey, J. (1983). A nation at risk: The report of the national commission on excellence in Education. Phi Delta Kappan, September 1983. Report in Schultz, Education 84/85. Guildford, CT: Pushkin, 1985, 74-74.

Hackett, G. (1985). Role of mathematics self-efficacy in the choice of math-related majors of college women and men: A path analysis. Journal of Counseling Psychology, 32(1), 47-56.

Hagen, A. S., \& Weinstein, C. E. (1995). Achievement goals, self-regulated learning, and the role of classroom context. In P. R. Pintrich (Ed.), New directions for teaching and learning (pp. 43-55). San Francisco, CA: Jossey-Bass.

Harper, N. J. W. (1994). The effect of a mathematics methods course on elementary preservice teachers' beliefs about the standards and their level of mathematics anxiety. Unpublished doctoral dissertation, University of Alabama, Tuscaloosa.

Hendel, D. D., \& Davis, S. O. (1978). Effectiveness of an intervention strategy for reducing mathematics anxiety. Journal of Counseling Psychology, 25, 429-434.

Hilton, P., \& Pedersen, J. (1983). Fear no more: An adult approach to mathematics. Menlo Park, CA: AddisonWesley.

Hinds, V, Hom, K, \& Brookshaw, K. (2002). Making waves. Proceedings of the Annual International Conference on the FirstYear Experience.

Hyde, J. S., Fennema, E., \& Lamon, S. J. (1990). Gender differences in mathematics performance. Psych Bull, 107, 139-155.

Jacob, E. (1999). Cooperative learning in context: An educational innovation in everyday classrooms. Albany, NY: State University of New York Press.

Jago, C. (2002). Cohesive Writing: Why Concept Is Not Enough. (ERIC Document Reproduction Service No. ED462691).

Johnson, D.W. \& Johnson, R.T. (1995). Cooperative learning and nonacademic outcomes of schooling: The other side of the report card. In J.E. Pedersen \& A.D. Digby (Eds.), Secondary schools and cooperative learning: Theories, models, and strategies. New York: Garland.

Johnson, D.W., Johnson, R.T. \& Smith, K.A. (1995). Cooperative learning and individual student achievement in secondary schools. In J.E. Pedersen \& A.D. Digby (Eds.), Secondary schools and cooperative learning: Theories, models, and strategies. New York: Garland.

Kaplan, A., Gheen, M., \& Midgley, C. (2002). Classroom goal structure and student disruptive behavior. British Journal of Educational Psychology, 72, 191-211.

Karabenick, S.A. (2004). Perceived achievement goal structure and college student help seeking. Journal of Educational Psychology, 96, 569-581.

Kohn, A. (1990). You know what they say. New York: HarperCollins.

Kramarski, B., Mevarech, Z. R., \& Arami, M. (2002). The Effects of Metacognitive Instruction on Solving Mathematical Authentic Tasks. Educational Studies in Mathematics, 49 (2), 225-50.

Krovetz, M., Casterson, D., McKowen, C. \& Willis, T. (1993). Beyond show and tell. Educational Leadership, 50(7), 7376.

Kumar, D., \& Voldrich, J.F. (1994). Situated cognition in second grade science: literature books for authentic contexts. Journal of Elementary Science Education, 6(2) , 110.

Kutner, L. (1992, August 13). Teachers and parents who are afraid of math can pass that anxiety to the next generation. The New York Times, pp. B4, C12.

Lane, N. (1999). International mathematical olympiad 2001 USA. Paper presented at the Secretary's Conference Room of the U.S. Department of Education. Retrieved on September 27, 2005 at: http://www.ostp.gov/html/ 0022 3.html. 
Lau, S. \& Nie, Y. (2008). Interplay between personal goals and classroom goal structures in predicting student outcomes: A multilevel analysis of person-context interactions. Journal of Educational Psychology, 100, 15-29.

Linnenbrink, E.A. (2005). The dilemma of performanceapproach goals: The use of multiple goal contexts to promote students' motivation and learning. Journal of Educational Psychology, 97(2), 197-213

Locke, E.A. \& Latham, G.P. (2002). Building a practically useful theory of goal setting and task motivation: A 35year odyssey. American Psychologist, 57, 705-717.

Maehr, M.L. \& Anderman, E.M. (1993). Reinventing schools for early adolescents: Emphasizing task goals. The Elementary School Journal, 93(5), 593-610.

McGregor, H.A. \& Elliot, A.J. (2002). Achievement goals as predictors of achievement-relevant processes prior to task engagement. Journal of Educational Psychology, 94(2), 381-395.

Meece, J.L. (1991). The classroom context and students' motivational goals. In M.L. Maehr and P.R. Pintrich's (Eds.), Advances in Motivation and Achievement, Vol. 7: (pp. 261-285). Greenwich, CT: JAI Press.

Meece, J. L., Blumenfeld, P. C., \& Hoyle, R. H. (1988). Students' goal orientations and cognitive engagement in classroom activities. Journal of Educational Psychology, 80, 514-523.

Meece, J.L. \& Miller, S.D. (1999). Changes in elementary school children's achievement goals for reading and writing: Results of a longitudinal and an intervention study. Scientific Studies of Reading,3(3), 207-229.

Middleton, M. J., \& Midgley, C. (1997). Avoiding the demonstration of lack of ability: An underexplored aspect of goal theory. Journal of Educational Psychology, 89, 710-718.

Midgley, C., Anderman, E., \& Hicks, L. (1995). Differences between elementary and middle school teachers and students: A goal theory approach. The Journal of Early Adolescence, 15(1), 90-113.

National Council of Teachers of Mathematics. (1989). Curriculum and evaluation standards for school mathematics. Reston, VA: Author.

National Council of Teachers of Mathematics. (1991). Professional standards for teaching mathematics. Reston, VA: Author.

National Council of Teachers of Mathematics. (1995a). Mathematics anxiety [Supplemental Brochure]. Reston, VA: Author.

National Council of Teachers of Mathematics. (1995b). Professional assessment standards for teaching mathematics. Reston, VA: Author.

National Council of Teachers of Mathematics. (2000). Curriculum and evaluation standards for school mathematics (2 ${ }^{\text {nd }}$ Ed.). Reston, VA: Author.

National Council of Teachers of Mathematics. (2006). Curriculum focal points for prekindergarten through grade 8 mathematics: A quest for coherence. Reston, VA: Author.

National Resource Council. (1989). Everybody counts: A report to the nation on the future of mathematics education. Washington, DC: National Academy Press.

Neunzert, H. (2000). Will Mathematics and the Mathematicians be able to contribute essentially in shaping the future? Paper presentation at the 3ECM Conference Round Table
Discussion on Shaping the 21st Century, Barcelona, Spain, July 11-14, 2000.

Oberlin, L. (1982). How to teach children to hate mathematics. School Science and Mathematics, 82, 261.

Paris, S.G. \& Paris, A.H. (2001). Classroom applications of research on self-regulated learning. Educationa Psychologist, 36(2), 89-101.

Patrick, H., Anderman, L.H., Ryan, A.M., Edeline, K.C., \& Midgley, C. (2001). Teachers' communication of goal orientations in four fifth-grade classrooms. The Elementary School Journal, 102(1), 35-58.

Pejouhy, N. H. (1990). Teaching math for the 21 st century. Phi Delta Kappan, 72(1), 76.

Perry, N.E., Vandekamp, K.O., Mercer, L,K., \& Nordby, C.J. (2002). Investigating teacher-student interactions that foster self-regulated learning. Educational Psychologist, 37(1), 5-15.

Pintrich, P. R., \& Garcia, T. (1991). Student goal orientation and self-regulation in the college classroom. In Advances in Motivation and Achievement, (Vol. 7). Greenwich, CT: JAI Press.

Proga, R. (2005). Math for the anxious: Building basic skills. Boston, MA: McGraw-Hill Higher Education.

Posamentier, A. S., Smith, B. S. \& Stepelman, J. (2009). Teaching secondary school mathematics: Techniques and teaching units, $8^{\text {th }} \mathrm{Ed}$. Columbus, OH: Merrill.

Putwain, D.W. \& Daniels, R.A. (2010). Is the relationship between competence beliefs and test anxiety influenced by goal orientation? Learning and Individual Differences, 20, 8-13.

Rawsthorne, L. J., \& Elliot, A. J. (1999). Achievement goals and intrinsic motivation: A meta-analytic review. Personality and Social Psychology Review, 3, 326-344.

Rech, J. F. (1994). A comparison of the mathematics attitudes of black students according to grade level, gender, and academic achievement. Journal of Negro Education, 63(2), 212-220.

Reilly, L. (1992). Study to examine math anxiety for students who are single parents and those enrolled in nontraditional career preparation programs. (ERIC Document Reproduction Service No. ED 359 380)

Resnick, H., Viehe, J., \& Segal, S. (1982). Is math anxiety a local phenomenon? A study of prevalence and dimensionality. Journal of Counseling Psychology, 29(1), 3947.

Rounds, J. B., \& Hendel, D. D. (1980). Mathematics anxiety attitudes toward mathematics. Measurement and Evaluation in Guidance, 13(2), 83-89.

Rubin, N. (1988, June). Math stinks! Parents Magaz̧ine, 63(6), 132-139.

Ruedy, E., \& Nirenberg, S. (1990). Where do I put the decimal point?: How to conquer math anxiety and increase your facility with numbers. New York: Henry Holt and Company.

Ryan, A.M., Gheen, M.H., \& Midgley, C. (1998). Why do some students avoid asking for help? An examination of the interplay among students' academic efficacy, teachers' social-emotional role, and the classroom goal structure. Journal of Educational Psychology, 90(3), 528-535.

Ryan, K.E., Ryan, A.M., Arbuthnot, K., \& Samuels, M. (2007). Students' motivation for standardized math exams. Educational Researchers, 36(1), 5-13. 
Sarason, I. G. (1987). Test anxiety, cognitive interference, and performance. In R. E. Snow \& M. J. Farr (Eds.), Aptitude, learning, and instruction: Volume 3: Conative and affective process analyses (pp. 131-142). Hillsdale, NJ: Erlbaum.

Sarason, S. (1993). The case for change. San Francisco, CA: Jossey-Bass.

Schack, G.D. (1993). Involving students in authentic research. Educational Leadership, 50(7), 29-31.

Schmidt, W. H. (1998). Changing mathematics in the U.S.: policy implications from the third international mathematics and science study. Presentation at the $76^{\text {th }}$ Annual meeting of the National Council of Teachers of Mathematics, Washington, D.C., April 3, 1998.

Schrenko, L. (1994). Structuring a learner-centered school. Pallatine, IL: IRI/Skylight Publishing.

Schunk, D.H. (1990). Goal setting and self-efficacy during self-regulated learning. Educational Psychologist, 25(1), 7186.

Schunk, D.H. (2001). Social cognitive theory and selfregulated learning. In B.J. Zimmerman \& D.H. Schunk (Eds.), Self-regulated learning and academic achievement: Theoretical perspectives. (2nd ed.). Mahwah, NJ: Erlbaum.

Schunk, D.H. \& Zimmerman, B.J. (1997). Social origins of self-regulatory competence. Educational Psychologist, 32(4), 195-208.

Sherard, W. H. (1981). Math anxiety in the classroom. The Clearing House, 75(5), 280-284.

Shih, S. (2005). Role of achievement goals in children's learning in Taiwan. Journal of Educational Research, 98(5), 310-319.

Sideridis, G.D. (2008). The regulation of affect, anxiety, and stressful arousal from adopting mastery-avoidance goal orientations. Stress and Health, 24, 55-69.

Skaalvik, E. M. (1997). Self-enhancing and self-defeating ego orientation: Relations with task and avoidance orientation, achievement, self-perceptions, and anxiety. Journal of EducationalPsychology, 89, 71-81.

Slavin, R.E. (1991). Synthesis of research on cooperative learning. Educational Leadership, 48(5), 71-77, 79-82.

Slavin, R.E. (1995). Cooperative learning: Theory, research, and practice ( $2^{\text {nd }}$ ed.). Boston: Allyn \& Bacon.

Steen, L.A. (1999). Numeracy: The new literacy for a datadrenched society. Educational Leadership, October, 8-13.

Stipek, D. (1998). Motivation to learn: From theory to practice, $\left(3^{\text {rd }}\right.$ ed.), Boston: Allyn \& Bacon.

Stipek, D. J., \& Kowalski, P. S. (1989). Learned helplessness in task-orienting versus performance-orienting testing conditions. Journal of Educational Psychology, 81, 384-391.

Tobias, S. (1987). Succeed with math: Every student's guide to conquering math anxiety. New York: College Board Publications.

Tobias, S. (1993). Overcoming math anxiety revised and expanded. New York: Norton.

Turner, J.C., Midgley, C., Meyer, D.K., Gheen, M., Anderman, E.M. \& Kang, Y. (2002). The classroom environment and students' reports of avoidance strategies in mathematics: A multimethod study. Journal of Educational Psychology, 94(1), 88-106.

Urdan, T. (1997). Achievement goal theory: Past results, future directions. In M.L. Maehr and P.R. Pintrich's
(Eds.), Advances in Motivation and Achievement, Vol. 10: (pp. 99-141). Greenwich, CT: JAI Press.

Vermette, P.J. (1998). Making cooperative learning work: Student teams in K-12 classrooms. Upper Saddle River, NJ: Merrill.

Wells, D. (1994). Anxiety, insight and appreciation. Mathematics Teaching, 147, 8-11.

Williams, W. V. (1988). Answers to questions about math anxiety. School Science and Mathematics, 88(2), 95-104.

Zimmerman, B.J. (1998). Developing self-fulfilling cycles of academic regulation: An analysis of exemplary instructional models. In D.H. Schunk \& B.J. Zimmerman (Eds.), Self-regulated learning: From teaching to self-reflective practice. New York: The Guilford Press.

Zimmerman, B.J., Bonner, S. \& Kovach, R. (1996). Developing self-regulated learners: Beyond achievement to self-efficacy. Washington, DC: American Psychological Association.

Zusho, A., Pintrich, P.R., \& Cortina, K.S. (2005). Motives, goals, and adaptive patterns of performance in Asian American and Anglo American students. Learning and Individual Differences, 15, 141-158. 


\section{Appendix A. Resource Summary for Math Anxiety}

Math Anxiety at a Glance: Resource Summary

What NCTM says about Mathematics Anxiety and Dispositions toward Mathematics?

Standard 10: Mathematical Disposition

As mathematics teachers, it is our job to assess students' mathematical disposition regarding:

$\checkmark$ confidence in using math to solve problems, communicate ideas, and reason;

$\checkmark$ flexibility in exploring mathematical idea and trying a variety of methods when solving;

$\checkmark$ willingness to persevere in mathematical tasks;

$\checkmark$ interests, curiosity, and inventiveness in doing math;

$\checkmark$ ability to reflect and monitor their own thinking and performance while doing math;

$\checkmark$ value and appreciate math for its real-life application, connections to other disciplines and cultures and as a tool and language
Appendix B. How to Prevent and Reduce Math Anxiety in a Nutshell

\section{To reduce math anxiety a teacher needs to:}

1. Use Psychological Techniques like anxiety management, desensitization, counseling, support groups, biblio-therapy, goal setting, discussions.

2. Once a student feels less fearful about math he/she may build their confidence by taking more mathematics classes, work toward mastery of subject matter.

3. Most research shows that until a person with math anxiety has confronted this anxiety by some form of discussion/counseling no "best practices" in math will help to overcome this fear.

\section{To prevent math anxiety a teacher needs to:}

1. Use "Best Practice" in mathematics such as: math manipulatives, cooperative groups, discussion of math, questioning and making conjectures, justification of thinking, writing about math, problem-solving approach to instruction, content integration, technology, assessment as an integral part of instruction, etc.

2. Incorporating the NCTM Standards and State Standards into curriculum and Instruction; Content knowledge and mastery learning must be emphasized.

3. Discussing feelings, attitudes, goals and goal setting, and appreciations for mathematics with students is very important. 